International Journal of Life Sciences
Available online at www.sciencescholar.us
Vol. 4 No. 3, December 2020, pages: 59-71
e-ISSN: 2550-6986, p-ISSN: 2550-6994
https://doi.org/10.29332/ijls.v4n3.550

\title{
Using Banana Peels in Pellet Rations to Improve Performance of Local Male Rabbits (Lepus nigricollis)
}

\author{
R. Rochia , G.A.M.K. Dewib, I.M. Nuriyasac
}

Manuscript submitted: 18 October 2020, Manuscript revised: 27 November 2020, Accepted for publication: 09 December 2020

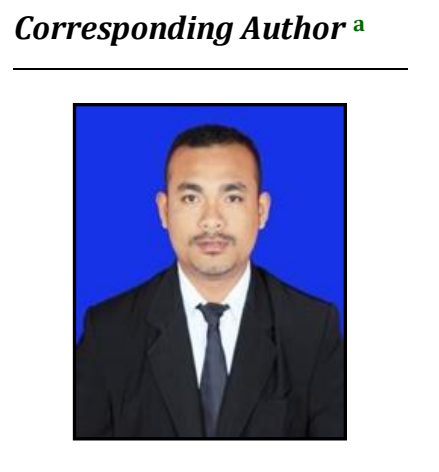

\section{Keywords}

banana peels; dry materials; local male rabbits; performance; treatments;

\begin{abstract}
A concise and factual abstract This study aims to find out the influence of the use of banana peels in pellet rations to improve the performance of local male rabbits (Lepus nigricollis). The study used 20 local male rabbits that were maintained from 5 to 12 weeks old. The study used Randomized Group Design with 4 treatments and 5 repeats. The treatments in this study are: Rabbit feed that did not contain banana peels (R0), Rabbit feed that contained 5\% banana peels (R1), Rabbit feed that contained $10 \%$ banana peel (R2), and Rabbit feed that contained $15 \%$ banana peel (R3). The results showed no noticeable difference $(\mathrm{P}>0.05)$ in the treatment of rations against the ingenuity of dry matter digestibility, energy digestibility, protein digestibility, protein consumption, consumption of dry materials, and Feed Conversion Ratio (FCR). Rabbits who get R1 ration treatment produce the final weight and the weight gain was significantly different $(\mathrm{P}<0.05)$ to $\mathrm{R} 0$ and $\mathrm{R} 3$ treatment, and not significantly different $(\mathrm{P}>0.05)$ on $\mathrm{R} 2$ treatment. $\mathrm{R} 1$ ration consumption is the highest $(\mathrm{P}<0.05)$ compared to $\mathrm{R} 0, \mathrm{R} 2$, and $\mathrm{R} 3$ treatments. The effect of ration treatment on carcass variables shows results significantly different $(\mathrm{P}<0.05)$.
\end{abstract}

International Journal of Life Sciences (C) 2020.

This is an open access article under the CC BY-NC-ND license (https://creativecommons.org/licenses/by-nc-nd/4.0/).

\section{Contents}

Abstract

1 Introduction.

2 Materials and Methods.

3 Results and Discussions...

Conclusion

Acknowledgments

References.

\footnotetext{
a Bachelor of Animal Husbandry Study Program, Faculty of Animal Husbandry, Udayana University, Denpasar, Bali, Indonesia

${ }^{\text {b }}$ Faculty of Animal Husbandry, Udayana University, Denpasar, Bali, Indonesia

c Faculty of Animal Husbandry, Udayana University, Denpasar, Bali, Indonesia
} 


\section{Introduction}

Livestock is an important component in farming in various places in Indonesia. Breeding Rabbits has good potential to be developed in small and large-scale businesses because rabbits can give birth 4-6 times a year with an average of 4-12 children a birth. Rabbit livestock is a livestock commodity that can produce meat with low cholesterol content and high in protein. Rabbit meat contains cholesterol of $47 \mathrm{mg} / 100 \mathrm{~g}$ lower meat compared to beef, lamb, pork, and chicken respectively 48.7, 52.3, 62.7, and 55.3 mg/100 g of meat (DalleZotte, 2014), therefore rabbit meat is good for human health, especially for people who avoid cholesterol. To produce good quality meat, farmers must pay attention to good feed as well, because feed is the most important part of the maintenance of livestock (Masanto \& Agus, 2010). To produce meat with good quality, farmers must pay attention to good feeding management also because feed is the determinant of livestock growth.

The problem that occurs in rabbit farms, in general, is the traditional feed management so that farmers do not pay attention to the adequacy of rabbit nutrition such as energy fulfillment, protein, and water. The key to the success of raising cut rabbits can provide feeds that meet the standards of nutrient needs cheaply because the cost of feed can reach $80 \%$ of the total cost of production. As we know, the growth pattern of livestock is strongly influenced by the quality and quantity of feed provided, meaning that the better the content of feed nutrients will increase livestock consumption and if the content of low feed ration consumption will also decrease. According to Lestari et al. (2014), Rabbits can grow and develop by utilizing various types of forage as a staple food, but forage feed is only enough to meet the basic needs of life so that its production will not be maximal. This problem can be solved by creativity utilizing local or unconventional feed materials that can be used as alternative feed as a commercial feed that can meet the nutritional needs of livestock, maintain and even improve the performance of rabbit livestock. One of them utilizes agricultural waste such as banana peels that are widely spread throughout the region in Indonesia with high nutrient content and not traded because it is considered as waste.

Banana fruit (Musa sapientum l.) is the second-largest fruit production in the world after oranges, while banana peels represent $40 \%$ of the weight of bananas (Alkarkhi et al., 2010). Banana production in Indonesia reached 7.26 million tons in 2018. Bananas so large consumed in the country. The large consumption indicates the high need of Indonesian people for fruit and has a new impact, namely increased waste production. Banana peel waste can be used as raw material for rabbit animal feed because banana peels contain quite good nutrients, especially carbohydrates. According to Aryani et al., (2018), banana peels contain water content of $6.61 \%$, ash $1.10 \%$, fat $6.37 \%$, protein $7.16 \%$, carbohydrates $76.20 \%$, fiber $36.60 \%$, calcium $0.34 \%$ and phosphorus $0.26 \%$, carotene $0.13 \%$, anthocyanins $15.61 \%$.

In addition to these nutrients banana peel also contains beta-carotene and antioxidants. The beta-carotene

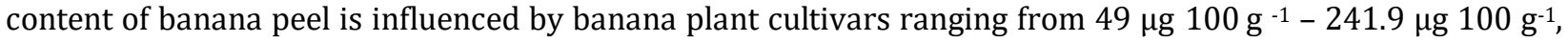
the highest levels of beta-carotene bananas in red (Arora et al., 2008; Emaga et al., 2008; Swamy \& Muthukumarappan, 2017). Banana peels have bioactive compounds and have an antioxidant capacity as a feed additive in broiler chickens (Chueh et al., 2019). Periera \& Maraschin (2015), further report banana peels can be a source of natural antioxidants and pro-vitamin A such as carotenoids, phenolics, and amin compounds estimated the total phenolic content of banana peels is three times higher than the fruit. Judging from the abundant production, not utilized and as a source of antioxidant compounds and containing high carbohydrates, the banana peel is very potential to be used as rabbit animal feed. Banana peels cannot be given directly to rabbit livestock, because the protein content is low in coarse, coarse fiber is high and its properties are easily decomposed, so it is necessary to process with physical treatment and then made flour.

To meet the needs of protein that is lacking in banana peels, other feed ingredients are needed as a source of additional protein, such as soybean meal, coconut meal, and fish meal. The feed material obtained will be arranged into rations then made in the form of pellets and given to local male rabbit livestock. The purpose of giving rations in the form of pellets is so that rabbits can make efficient use of rations. Dozier (2001), stated that rations in the form of pellets can increase the availability of nutrients in feed, facilitate handling thereby lowering production costs and reducing depreciation. 
The potential of banana peels has been studied in some livestock including cattle, goats, pigs, and chickens, but not many banana skin potentials are utilized in rabbit livestock. The results of Oliveira et al. (2016), stated that the combination of banana peels and papaya leaves with different concentrations can affect the nutritional content of the pellet. Pellet with a concentration of $6 \%$ banana peel kepok and $18 \%$ papaya leaves closest to the nutritional value needed rabbits. Amri (2019), reported that the addition of banana peels flour kepok to the level of $6 \%$ in local male rabbit growth period got an average cut weight of 1,980 g/tail, average carcass weight of $1,074 \mathrm{~g} /$ tail, and average carcass percentage of $54.67 \%$.

From one of the banana peels composition is a nutritional need of rabbit cattle cut for important components in the process of feed making materials including carbohydrates. Carbohydrates are an important feed ingredient as an energy source, the main function of carbohydrates in rabbit rations again for energy needs and metabolic processes in the body of livestock. Banana peel is expected to meet the energy source in rabbits because it contains quite high carbohydrates which are $76.20 \%$. This is following Nuriyasa (2012). The opinion that carbohydrates and fats an energy source for rabbit livestock. Based on the background above, research was conducted on the influence of banana peel use in pellet rations to improve the performance of local male rabbits (Lepus nigricollis).

\section{Materials and Methods}

\section{Rabbit}

The livestock used in this study were local male rabbits released 5 weeks old as much as 20 heads with an average initial body weight of $317.50 \pm 10.85 \mathrm{gr}$.

\section{Research Cage}

The cage used in this study is a cage "batrrery" with as many as 20 units of cage boxes with a measuring length of $75 \mathrm{~cm}$, a width of $45 \mathrm{~cm}$, and a height of $45 \mathrm{~cm}$. In each cage, the unit is filled with one rabbit. Each cage unit is equipped with a feed place and a drinking place made of coconut shells. Under each cage, the unit is placed used cardboard as a placeholder for dirt and the remnants of spilled feed so that it is easier to clean. Cleaning of the cage is carried out every afternoon.

\section{Banana Peels}

This study will use banana peel waste obtained from roadside fried food sales place. The process of processing banana peels flour is done by first preparing the banana peels after it is minced using a knife with a size of \pm 1 $2 \mathrm{~cm}$, then the banana skin is dried in the sun until the weight is constant, after which the banana peels are finely ground until it becomes flour.

\section{Treatment}

This study used Randomized Group Design with 4 treatments and 5 tests. The treatment is carried out based on the level of use of banana peel flour in the ratio of the pellet. The treatment given is: Rabbit feed that did not contain banana peels (R0), Rabbit feed that contained 5\% banana peels (R1), Rabbit feed that contained $10 \%$ banana peel (R2), and Rabbit feed that contained 15\% banana peel (R3).

\section{Research Variables}

Digestibility Variables

Dry matter digestibility, energy digestibility, and protein digestibility calculated based on data consumption of rations and content of dry matter digestibility, energy, and protein contained in feces.

1. Dry matter digestibility

Dry matter digestibility (DMD) will be calculated based on the total collection method (Tillman et al., 1998). Faeces accommodated for 7 days and dried in the sun until dry air and then in the oven at a temperature of $60^{\circ} \mathrm{C}$ for 24 hours. DMD is calculated by formulation:

$$
\mathrm{DMD}=\frac{(A-B)}{A} \times 100 \%
$$

Rochi, R., Dewi, G., \& Nuriyasa, I. (2020). Using banana peels in pellet rations to improve performance of local male rabbits (Lepus nigricollis). International Journal of Life Sciences, 4(3), 59-71. 
Description:

DMD: Dry Matter Digestibility (\%)

A: Consumption of dry ingredients ration (g)

B: Amount of feces dry matter (g)

2. Energy Digestibility

Energy digestibility will be calculated based on the total collection method (Tillman et al., 1998). Digestibility energy (DE) will be calculated by formulation:

$$
(\mathrm{DE})=\frac{(A-B)}{A} \times 100 \%
$$

Description:

(DE): Digestibility energy (\%)

A: Energy consumption (kcal/day)

B: Energy content of feces

3. Protein Digestibility

Protein digestibility will be calculated based on the total collection method (Prasad et al., 1996). Digestibility protein (DP) calculated with using formulation:

$$
\mathrm{DP}=\frac{(A-B)}{A} \times 100 \%
$$

Description:

DP : Digestibility Protein (\%)

A : Protein consumption(g/day)

B : Protein content of feces (g/day)

\section{Performance Variables}

The performance variables observed in this study include:

1) Consumption of rations

Consumption of rations is calculated every week by reducing the number of rations given with the remaining rations on the day. Total ration consumption was obtained by summing up the consumption of rations every week during the study.

2) Consumption of dry matter

Consumption of dry matter is determined by multiplying the consumption of rations with the content of dry feed ingredients according to the data of proximate analysis results (g/day).

3) Energy consumption

Energy consumption is determined by multiplying the consumption of rations with the energy content of rations according to the data of the results of proximate analysis (Kcal/g/day).

4) Protein consumption

Protein consumption is determined by multiplying the consumption of rations with ration protein content according to data from proximate analysis (g/day).

5) Drinking water consumption

Drinking water consumption is obtained by increasing the amount of drinking water given with the rest the next day. Measurements are carried out using measuring glasses.

6) Weight

Weight loss is done every 2 weeks to gain weight. Initial weight weighing was carried out at the beginning of the study to gain initial weight, while weight weighing was carried out at the end of the study to gain final weight. To find out weight gain during the study was done by reducing weight at the end of the study with weight at the beginning of the study. Before weighing the rabbit is satisfied for 12 hours.

7) Feed conversion ratio (FCR)

Feed Conversion Ratio (FCR) was calculated by the comparison between the amount of ration consumed with weight gain during the study. 
Carcass variables

Carcass data obtained by cutting rabbit livestock at the age of 84 days. Slaughter of rabbit livestock begins by cutting the jugular vein on the neck to expel blood (Alhaidary et al., 2010). The body of the rabbit is then hung on one of the hind legs by cutting the skin between the bone and the tendon on the elbow joint of the hind leg. The head is cut off in the cervical vertebrae, the hind legs in the elbow joint (Metatarsus), and the forefoot in the elbow joint (Metacarpus). The tail is released at its base (Caudal vertebrae). The skin is removed by making an incision at the back of the hamstring towards the base of the tail and a free thigh, then pulled towards the neck until it comes off. Offal is removed from the abdominal cavity by making a median incision in the abdominal wall. Empty weight gained by removing offal with lungs fixed with the carcass. Carcass percentage calculated based on a comparison between fresh carcass weight and cut weight multiplied by 100 (Lukefahr et al., 1982). Commercial cutting of carcasses is done utilizing carcasses cut into 2 pieces of left and right hind legs, one-piece waist and back, 2 pieces of chest and neck, and 2 pieces of left and right front legs (Sartika \& Raharjo, 1991).

\section{Results and Discussions}

Data from the study showed that the use of banana peels up to the level of 15\% in pellet rations showed no significantly different results $(\mathrm{P}>0.05)$ against the variable dilution of dry matter digestibility, digestibility energy, and digestibility protein (Table 5.1). Rabbits were given R1 rations resulted in the highest dry matter digestibility value of $69.96 \%$, while rabbits were given R0, R2 and R3 rations were $1.85 \%, 1.13 \%$, and $2.86 \%$ lower $(\mathrm{P}>0.05)$ than rabbits given $\mathrm{R} 1$ rations. The high ingest value of dry materials in the R1 treatment is possible because the consumption of rations (Table 5.2) in the same treatment is also high. High consumption of rations will affect how much nutrients can be digested and absorbed by the body of livestock to meet basic living needs, production, and reproduction. This is following the statement of Mcdonald et al., (2010), that the high dilution of dry ingredients is influenced by the amount of feed consumed. In addition to the consumption of rations, the role of phytochemical compounds contained in banana peels also has a positive impact on the dry matter digestibility. Based on phytochemical analysis results, the banana peel contains saponin compounds. Saponin compounds on banana peels have a role as protozoan killers, in other words, saponin compounds can suppress the growth of protozoa in the digestive tract of rabbit livestock. We know protozoa are parasitic microorganisms that multiply by eating bacteria in the digestive tract. With the decrease in protozoan growth, the number of bacteria in the digestive tract increases so that the process of absorption of food substances in the digestive channel takes place properly. Cheeke (2000), reported use of saponin compounds has anti-protozoan activity. According to Habibah \& Abun (2012), saponin compounds play a role in the digestive process by increasing the permeability of cell walls in the intestine and increasing the absorption of food substances. Saponin levels in rations will also improve nutrient transport between cells.

Tabel 1

Digestibility (\%) nutrition from local male rabbits given pellet rations banana peel

\begin{tabular}{llllll}
\hline \multirow{2}{*}{ Variable } & \multicolumn{5}{c}{ Treatment } \\
\cline { 2 - 6 } & R0 & R1 & R2 & R3 & SEM \\
\hline Dry matter digestibility (\%) & $68,67^{\mathrm{a}}$ & $69,96^{\mathrm{a}}$ & $69,18^{\mathrm{a}}$ & $67,96^{\mathrm{a}}$ & 0,64 \\
Energy digestibility (\%) & $70,15^{\mathrm{a}}$ & $71,85^{\mathrm{a}}$ & $71,44^{\mathrm{a}}$ & $70,94^{\mathrm{a}}$ & 0,63 \\
Protein digestibility (\%) & $71,56^{\mathrm{a}}$ & $74,03^{\mathrm{a}}$ & $72,05^{\mathrm{a}}$ & $71,72^{\mathrm{a}}$ & 0,71 \\
\hline
\end{tabular}

R0: Rabbit feed that did not contain banana peels, R1: Rabbit feed that contained 5\% banana peels, R2: Rabbit feed that contained 10\% banana peel and R3: Rabbit feed that contained 15\% banana peel, Means with different superscripts are significantly different $(\mathrm{p}<0.05)$, SEM: Standard error of the treatment means.

The average digestibility energy in this study was almost the same, but the higher in R1 treatment was $71.85 \%$ which statistically did not differ significantly from the treatment of Ro, R2, and R3 which was 70.15\%, $71.44 \%$, and $70.94 \%$. This happens because the consumption of energy and dry matter in R1 is also high

Rochi, R., Dewi, G., \& Nuriyasa, I. (2020). Using banana peels in pellet rations to improve performance of local male rabbits (Lepus nigricollis). International Journal of Life Sciences, 4(3), 59-71. https://doi.org/10.29332/ijls.v4n3.550 
(Table 1), thus affecting the high value of digestibility energy in the same treatment. The results of Xue et al., (2011) states that high GE consumption following the concentrate level given can have an impact on the cermined energy produced. High energy ingenuity in R1 treatment, also caused by the lowest crude fiber content of R1 ration (14.20\%) so that the coefficient of ration digestible increases and digestible energy also increases, as conveyed by Tillman et al. (1998). The value of ingested energy in this treatment can be said to be high because (Harhap, 2011) reports that nutrient ingenuity is high when the value is $70 \%$ and low when the value is less than $50 \%$.

Based on Table 1 it appears that the largest digestibility protein value is in R1 treatment (ration with banana peel use 5\%) namely $74.03 \%$ and the smallest is the treatment of R0 (ration without the use of banana peel) which is $71.56 \%$. The high and low ingenuity value of this protein is due to the protein content of rations and the consumption of different proteins for each treatment. This is following the opinion of Prawitasari et al. (2012), that the factor that affects protein dilution is the protein content in the feed, the higher the protein contained in the feed, the higher the protein consumption so that the value of protein dilution will be high as well. Another factor is caused by the content of flavanoid compounds on banana peels that serve as antibacterial. The way flavanoid compounds work in the digestive tract of livestock is by inhibiting the growth of pathogenic bacteria such as Escherichia coli, because if the growth of these bacteria increases can be pathogenic and cause diarrheal disease in livestock, which ultimately affects the process of absorption of nutrients that are not maximal. This may cause protein dilution value in pellet ration treatment without using banana peel (R0) lower than the treatment by using banana peel 5\% (R1). Ananta et al. (2018), states that banana peel extract with concentrations of $0.5 \%, 0.6 \%, 0.7 \%, 0.8 \%, 0.9 \%, 1 \%, 2 \%, 4 \%, 6 \%, 8 \%$ and $10 \%$ inhibits Escherichia coli bacteria with different bland zone diameters. The most optimal concentration of banana peel extract in inhibiting $E$. coli is a concentration of $10 \%$ with a bland zone of $17.15 \mathrm{~mm}$. The results of Sartika and Herdiana research (2019) showed the average growth of E. coli before banana peel extract was added by 8 logs of 1.8 colonies/g. After the addition of banana skin extract, the average growth of E. coli dropped to 7 logsof 3.0 colonies/g. The value of digestibility protein in this study did not differ much from that obtained (Kusuma, 2016), which got the average range of protein to ingest of local male rabbits aged 17 weeks, namely $70.79 \%-78.11 \%$.

The effect of banana peels pellet ration treatment is different from the average performance of local male rabbits presented in Table 2. Based on the data of fingerprint analysis there is a significantly different $(\mathrm{P}<0.05)$ in the variable consumption of rations. The use of banana peels pellet rations at the levels of $5 \%$, $10 \%$, and $15 \%$ showed higher results than control rations (Table 2). The high consumption of rations is caused because banana peels contain compounds that serve as antioxidants such as flavanoids, phenolics, and saponins. According to Kanazawa \& Sakakibara (2000), banana peels contain bioactive compounds such as flavanoids, catecholamines, and dopamine that serve as antioxidants. The research Fatemeh et al. (2012), which tested the antioxidant activity of banana skin flour, obtained antioxidant activity results of $45.08 \pm 1.30 \%$ for flour from ripe banana skin and $52.66 \pm 0.82 \%$ for flour from the immature banana peel (green color). The role of flavanoid compounds as antibacterials can inhibit the growth of pathogenic bacteria such as Escherichia coli and Salmonella typhimurium in the digestive tract of local male rabbits, thereby causing increased consumption of rabbit rations. Tribudi et al. (2020) reported that giving red jeringau extract containing flavanoid compounds in broiler chicken drinking water infected with Salmonella typhimurium can increase feed consumption compared to control. Daud \& Zulfan (2018), reported the use of $4 \%$ fermented banana peel flour in commercial rations of peking ducks aged 3-8 weeks resulted in consumption of rations of $4,850.52 \pm 27.40 \mathrm{~g} /$ tail higher than the control of $4.387 .80 \pm 195.56 \mathrm{~g} / \mathrm{tail}$.

There was no significant difference $(\mathrm{P}>0.05)$ between the dry matter consumption variable, energy consumption, and protein consumption (Table 2). Average consumption on these three variables showed relatively the same results but tended to be higher in the R1 treatment. This is because the energy content of rations of each treatment is also almost the same, where based on the data of ration treatment proximate, R1 contains GE of $3856 \mathrm{Kcal} / \mathrm{g}$, R0 (3853 Kcal/g), R2 (3842 Kcal/g), and R3 (3857 Kcal/g). This is following Wuysang et al. (2016), the relatively same energy in each ration causes rabbits to consume almost the same amount of rations. Wardhana et al. (2014), stated that the energy content of feed affects energy consumption, the higher the energy content in feed will lead to low energy consumption. Aisjah et al. (2007), which states that the administration of rations that have the same metabolic energy content will produce the same 
consumption of rations, as well as rations that have the same protein content will produce the same protein consumption.

Table 2 shows the final average weight and weight gain in local male rabbits given banana skin pellet ration up to $15 \%$ level showing results significantly different $(\mathrm{P}<0.05)$. The use of banana peel $5 \%$ in pellet rations showed significantly different $(\mathrm{P}<0.05)$ compared to $\mathrm{R} 0, \mathrm{R} 1$, and $\mathrm{R} 2$ treatments. The height of the final weight and weight gain is due to the high consumption of rations in the R1 treatment, in other words, the intake of nutrients, especially protein and energy also increases, thus leading to optimal growth. Atmaja \& Krishna (2020), report that the final body weight is influenced by the amount of feed consumed and nutrients absorbed in the rabbit's body, nutrients absorbed more by rabbit livestock will give the final body weight higher. Soeparno (2005), argues that higher protein and energy consumption will result in a faster growth rate. Energy and protein are the main constituent components of body tissues (Nuriyasa et al., 2018). Another factor is due to the absorption of feed substances that are good for the growth and formation of tissues that are contained active compounds in banana peels. Active compounds in the form of flavonoids and high phenolics can inhibit the growth of pathogenic bacteria in rabbit livestock. According to Khalil (1999), phenol compounds in banana peels can kill pathogenic bacteria (bactericides). Ulfa \& Natsir (2018), reported the addition of sambiloto leaf extract by $0.4 \%$ in feed can increase the weight gain of chickens by $8.82 \%$ compared to the control of sambiloto leaves containing active compounds including flavonoids, glycosides, saponins, and andrographolide. Daud \& Zulfan (2018), reported the use of $4 \%$ fermented banana skin flour in commercial rations of peking ducks aged 3-8 weeks resulted in final weight gain and weight gain of 1,366.04 \pm 188.18894 and $180.44 \pm 19,51$ more than the controls of 1,361.88 \pm 45.46 and $180.24 \pm 17,67$.

Table 2

Effect of pellet ration treatment containing different banana skin on rabbit performance

\begin{tabular}{lccccc}
\hline \multirow{2}{*}{ Variable } & & \multicolumn{3}{c}{ Treatment } & \multirow{2}{*}{ SEM } \\
\cline { 3 - 5 } & $\mathrm{R} 0$ & $\mathrm{R} 1$ & $\mathrm{R} 2$ & $\mathrm{R} 3$ & \\
\hline Final weight loss (g) & $17,39,80^{\mathrm{b}}$ & $1993,60^{\mathrm{a}}$ & $1867,60^{\mathrm{ab}}$ & $1762,00^{\mathrm{b}}$ & 52,18 \\
Weight gain (g/day) & $16,79^{\mathrm{b}}$ & $20,10^{\mathrm{a}}$ & $18,52^{\mathrm{ab}}$ & $17,13^{\mathrm{b}}$ & 0,63 \\
Consumption of rations (g/day) & $62,12^{\mathrm{c}}$ & $73,81^{\mathrm{a}}$ & $68,20^{\mathrm{b}}$ & $63,17^{\mathrm{c}}$ & 1,58 \\
Consumption of dry matter (g/day) & $54,48^{\mathrm{a}}$ & $58,69^{\mathrm{a}}$ & $55,57^{\mathrm{a}}$ & $53,06^{\mathrm{a}}$ & 3,27 \\
Energy consumption (Kcall/day) & $237,41^{\mathrm{a}}$ & $262,72^{\mathrm{a}}$ & $247,24^{\mathrm{a}}$ & $240,33^{\mathrm{a}}$ & 14,50 \\
Protein consumption (g/day) & $11,92^{\mathrm{a}}$ & $15,22^{\mathrm{a}}$ & $13,34^{\mathrm{a}}$ & $13,20^{\mathrm{a}}$ & 0,79 \\
Feed Conversion Ratio (FCR) & $3,70^{\mathrm{a}}$ & $3,68^{\mathrm{a}}$ & $3,69^{\mathrm{a}}$ & $3,71^{\mathrm{a}}$ & 0,08 \\
\hline
\end{tabular}

R0: Rabbit feed that did not contain banana peels, R1: Rabbit feed that contained 5\% banana peels, R2: Rabbit feed that contained 10\% banana peel and R3: Rabbit feed that contained 15\% banana peel, Means with different superscripts are significantly different $(\mathrm{p}<0.05)$, SEM: Standard error of the treatment means.

The results showed that banana peel usage up to $15 \%$ in pellet rations showed results no significantly different $(\mathrm{P}>0.05)$ against feed conversion ratio (FCR) variables (Table 2). Rabbits who have treated and with pellet ration treatment with the use of banana peels $5 \%, 10 \%, 15 \%$, and without the use of banana peels produced FCR 3.68, 3.69, 3.71, and 3.70 (Table 2). The difference in FCR value is closely related to ration consumption and weight gain.

The presence of active substances in the form of flavanoids as antioxidants in the body of rabbits can increase weight gain and consumption of rations so that it affects FCR rations in R1 and R2 treatments better than rabbits who are not treated with banana peels. Flavonoids are antimicrobial phenol compounds that are disinfectant and bacteriosis that work by denaturing proteins and forming complex compounds against extracellular proteins that can interfere with the integrity of cell membranes and walls and stop bacterial cell metabolic activity (Guevara et al., 1999). Alkaloids, terpenoids, saponins, and phenolics are other compounds contained in banana peels that are antimicrobial to kill pathogenic microbes in the digestive tract and good microbes can increase. Thus the chances of absorption of feed nutrients are more optimal so that it has an impact on increasing the growth of local male rabbit livestock. The increasing growth of rabbits causes the need for food substances are also increasing, to support the rapid growth of ration consumption is also

Rochi, R., Dewi, G., \& Nuriyasa, I. (2020). Using banana peels in pellet rations to improve performance of local male rabbits (Lepus nigricollis). International Journal of Life Sciences, 4(3), 59-71. https://doi.org/10.29332/ijls.v4n3.550 
increasing, this happens because in banana skin there are substances that can inhibit the growth of pathogenic bacteria in the digestive tract (Wiryawan et al., 2005) so that the use of banana peels in pellet rations can increase feed consumption in rabbits better by producing high weight gain and low ration conversion between treatments. Miah et al. (2004), reported that the administration of saponins in nonruminant animal feed is known to increase the growth and efficiency of feed and improve the quality of livestock meat. The results of this study are still in the normal range, where according to De-Blass \& Wiseman (1998), the conversion range of rabbit rations is 3.0 to 4.0 .

Rabbits that were kept for 84 days and given ration treatment with the use of banana peel 5\% (R1) produced the highest average cut weight of $1949.40 \mathrm{~g}$, higher $(\mathrm{P}<0.05)$ than the R0, R2, and R3 treatments (Table 3). This is because rabbits who get R1 treatment consume more rations than other treatments, meaning that the higher the consumption of rations, the higher the intake of nutrients, especially protein and energy absorbed into the body of livestock so that growth becomes optimal. This statement is supported by Atmoko (2008), that the weight of the cut is influenced by the consumption of rations. The higher the consumption of rations, the higher the food substances that enter the body so that the growth of livestock is better and finally able to increase the weight of the cut. Nuriyasa et al. (2018), also argues that energy and protein consumption is the main component of body tissue constituents.

Table 3

Effect of pellet ration treatment containing different banana peel on rabbit carcasses

\begin{tabular}{lccccc}
\hline \multirow{2}{*}{ Variable } & \multicolumn{4}{c}{ Treatment } & \multirow{2}{*}{ SEM } \\
\cline { 2 - 5 } & R0 & R1 & R2 & R3 & \\
\hline Weight Cut (g) & $1704,80^{\mathrm{b}}$ & $1949,40^{\mathrm{a}}$ & $1828,40^{\mathrm{ab}}$ & $1731,60^{\mathrm{b}}$ & 48,51 \\
Carcass Weight (g) & $761,80^{\mathrm{b}}$ & $958,80^{\mathrm{a}}$ & $911,00^{\mathrm{a}}$ & $796,00^{\mathrm{ab}}$ & 43,46 \\
Carcass Percentage (\%) & $44,69^{\mathrm{a}}$ & $49,75^{\mathrm{a}}$ & $49,11^{\mathrm{a}}$ & $46,03^{\mathrm{a}}$ & 1,86 \\
\hline
\end{tabular}

R0: Rabbit feed that did not contain banana peels, R1: Rabbit feed that contained 5\% banana peels, R2: Rabbit feed that contained $10 \%$ banana peel and R3: Rabbit feed that contained $15 \%$ banana peel, Means with different superscripts are significantly different $(p<0.05)$, SEM: Standard error of the treatment means.

The effect of banana peel usage up to $15 \%$ in local male rabbit rations on carcass weight variables shows results significantly different $(\mathrm{P}<0.05)$ (Table 3$)$. The highest average carcass weight was obtained by treatment R1, namely 958.80 g compared to treatment R0, R2, and R3 (Table 3). The high weight of the carcasses in the R1 treatment is closely related to the variable weight of the cut. Brahmantiyo et al. (2010), states that the higher the cut weight the higher the carcass weight, and vice versa. It is added that the production of carcasses reflected by the meat, fatty, and rabbit looks strongly influenced by the weight of the cut. The high carcass weight in R1 is also due to high energy and protein consumption (Table 2). Damanik (2014), reported that higher protein consumption will result in a faster growth rate, thus increasing the ability of livestock to deposit proteins and other nutrients obtained from rations into meat, bone, and fat which are carcass-forming components. The result of this study is higher than that obtained by Nuriyasa (2012), who obtained the average weight of local male rabbit carcasses aged 84 days was $719.13 \mathrm{~g}$. The difference in results is due to differences in initial weight and the type of ration given.

Rabbits who get R1 treatment average carcass percentage of $49.75 \%$ which is statistically no significantly different $(\mathrm{P}>0.05)$ with $\mathrm{R} 0, \mathrm{R} 2$, and $\mathrm{R} 3$ treatment (Table 3$)$. The difference in yield is due to the high carcass weight produced by rabbits that have a higher cut weight (Table 3). Carcass production is reflected in the meat, fat, and bone components of rabbits that are heavily influenced by their cutting weight (Brahmantyo and Raharjo, 2009). The results of this study are not much different from Nuriyasa (2012), which obtained the percentage of local rabbit carcasses kept for 84 days which was cut at the same cut weight and age was $45.82 \%$. 


\section{Conclusion}

The use of banana peel in pellet rations local male rabbits at a level of $5 \%$ resulted in higher consumption of rations, digestibility, growth, and carcass weight than observed in rabbits fed diets containing $10 \%, 15 \%$, and no banana peels.

\section{Suggestion}

Based on the results of the research obtained can be suggested for rabbit breeders who want to use banana peels as additional feed-in rations to use banana peels as much as $5 \%$, because it can improve the ingenuity performance of local male rabbit livestock.

Acknowledgments

We are grateful to two anonymous reviewers for their valuable comments on the earlier version of this paper.

Rochi, R., Dewi, G., \& Nuriyasa, I. (2020). Using banana peels in pellet rations to improve performance of local male rabbits (Lepus nigricollis). International Journal of Life Sciences, 4(3), 59-71. https://doi.org/10.29332/ijls.v4n3.550 


\section{References}

Aisjah, T., \& Wiradimadja, R. Abun. (2007). Suplementasi metionin dalam ransum berbasis lokal terhadap imbangan efisiensi protein pada ayam pedaging. Artikel Ilmiah Jurusan Ilmu Nutrisi dan Makanan Ternak, Fakultas Peternakan, Universitas Padjajaran, Jatinangor, Bandung.

Alhaidary, A., Mohamed, H. E., \& Beynen, A. C. (2010). Impact of dietary fat type and amount on growth performance and serum cholesterol in rabbits. Am. J. Anim. Vet. Sci, 5(1), 60-64.

Alkarkhi, A. F., Saifullah, R., Yong, Y., \& Azhar, M. E. (2010). Physicochemical properties of banana peel flour as influenced by variety and stage of ripeness: multivariate statistical analysis. Asian Journal of Food and Agro-Industry, 3(3), 349-362.

Amri, N. (2019). Emberian Pellet Berbahan Tepung Kulit Pisang Kepok (Musa paradisiaca L.) Terhadap Karkas Kelinci Jantan Lokal Periode Pertumbuhan (Doctoral dissertation, Uniersitas Islam Negeri Sultan Syarif Kasim Riau).

Ananta, I. G. B. T., Rita, W. S., \& Parwata, I. M. O. A. (2018). Potensi Ekstrak Limbah Kulit Pisang Lokal (Musa sp) Sebagai Antibakteri Terhadap Escherichia coli dan Staphylococcus Aureus. Cakra Kimia (Indonesian EJournal of Applied Chemistry), 6(1), 21-29.

Arora, A., Choudhary, D., Agarwal, G., \& Singh, V. P. (2008). Compositional variation in $\beta$-carotene content, carbohydrate and antioxidant enzymes in selected banana cultivars. International journal of food science \& technology, 43(11), 1913-1921.

Aryani, T., Mu'awanah, I. A. U., \& Widyantara, A. B. (2018). Karakteristik fisik, kandungan gizi tepung kulit pisang dan perbandingannya terhadap syarat mutu tepung terigu.JRST Jurnal Riset Sains dan Teknologi), 2(2), 45-50.

Atmaja, I. G. M., \& Kresna, A. B. (2020). Performa dan Karkas Kelinci Jantan Lokal (Lepus nigricollis) yang diberi Ransum Megandung Limbah Wine Anggur Terfermentasi. AgriHumanis: Journal of Agriculture and Human Resource Development Studies, 1(1), 68-76.

Atmoko, G. T. (2008). Pengaruh penambahan tepung lempuyang (Zingiber aromaticum. Val) dalam ransum terhadap produksi karkas kelinci New Zealand White jantan.

Brahmantiyo, B. R. A. M., Raharjo, Y. C., Martojo, H., \& Mansjoer, S. S. (2010). Performa produksi kelinci Rex, Satin dan persilangannya. JITV, 15(2), 131-137.

Cheeke, P. R. (2000). Actual and potential applications of Yucca schidigera and Quillaja saponaria saponins in human and animal nutrition. In Saponins in food, feedstuffs and medicinal plants (pp. 241-254). Springer, Dordrecht.

Chueh, C. C., Lin, L. J., Lin, W. C., Huang, S. H., Jan, M. S., Chang, S. C., ... \& Lee, T. T. (2019). Antioxidant capacity of banana peel and its modulation of Nrf2-ARE associated gene expression in broiler chickens. Italian Journal of Animal Science, 18(1), 1394-1403.

Dalle Zotte, A. (2014). Rabbit farming for meat purposes. Animal Frontiers, 4(4), 62-67.

Damanik, N. S. (2014). Pengaruh Penambahan Asam Gelugur (Garcinia Atroviridis) Dalam Ransum Terhadap Persentase Karkas Dan Komponen Karkas Kelinci Peranakan New Zealand White. Students e-Journal, 3(1).

Daud, M., \& Zulfan, M. (2018). Subsitusi Kulit Pisang Fermentasi Dalam Ransum Komersial Terhadap Performan Itik Peking Fermented Banana Skin Substitution In Commercial Rations Against The Performance Of Peking Ducks.

De-Blass, C. \& J. Wiseman. (1998). The Nutrition of The Rabbit. CABI Publisher. University of Nottingham. Nottingham.

Dozier, W. A. (2001). Pellet quality for most economical poultry meat. J. Feed Int, 52(2), 40-42.

Emaga, T. H., Ronkart, S. N., Robert, C., Wathelet, B., \& Paquot, M. (2008). Characterisation of pectins extracted from banana peels (Musa AAA) under different conditions using an experimental design. Food chemistry, 108(2), 463-471. https://doi.org/10.1016/j.foodchem.2007.10.078

Fatemeh, S. R., Saifullah, R., Abbas, F. M. A., \& Azhar, M. E. (2012). Total phenolics, flavonoids and antioxidant activity of banana pulp and peel flours: influence of variety and stage of ripeness. International Food Research Journal, 19(3), 1041.

Guevara, A. P., Vargas, C., Sakurai, H., Fujiwara, Y., Hashimoto, K., Maoka, T., ... \& Nishino, H. (1999). An antitumor promoter from Moringa oleifera Lam.Mutation Research/Genetic Toxicology and Environmental Mutagenesis, 440(2), 181-188. https://doi.org/10.1016/S1383-5718(99)00025-X 
Habibah, A. S., \& Abun, W. R. (2012). Pengaruh Pemberian Ekstrak Kulit Jengkol (Pithecellobium juringa (Jeck) Pain dalam Ransum terhadap Performan Ayam Broiler. Artikel Ilmiah. Fakultas Peternakan. Universitas Padjadjaran. Bandung.

Harahap, Y. P. (2011). Pelepah dan Daun Kelapa Sawit Terfermentasi oleh Aspergillus niger Dalam Konsentrat Terhadap Kecernaan Bahan Kering dan Bahan Organik Ransum Pada Sapi iiiBali (Bos sondaicus).

Kanazawa, K., \& Sakakibara, H. (2000). High content of dopamine, a strong antioxidant, in cavendish banana. Journal of agricultural and food chemistry, 48(3), 844-848.

Khalil, N. (1999). TGF- $\beta$ : from latent to active. Microbes and infection, 1(15), 1255-1263. https://doi.org/10.1016/S1286-4579(99)00259-2

Kusuma, I.G.P.E. (2016). Performans dan Karkas Kelinci Lokal (Lepus nigricollis) yang diberi Pakan Dasar Rumput Lapangan dengan Suplementasi Multi Nutrien Block (MNB). (Tesis):Universitas Udayana. Denpasar.

Lestari, C. M., Wahyuni, H. I., \& Susandari, L. (2014). Budidaya Kelinci Menggunakan Pakan Limbah

Lukefahr, S., Hohenboken, W. D., Cheeke, P. R., Patton, N. M., \& Kennick, W. H. (1982). Carcass and meat characteristics of Flemish Giant and New Zealand White purebred and terminal-cross rabbits. Journal of Animal Science, 54(6), 1169-1174.

Masanto, R., \& Agus, A. (2010). Beternak Kelinci Potong. PT Niaga Swadaya.

McDonald, P., Edwards, R. A., Greenhalgh, J. F. D., \& Morgan, C. A. Sinclair. LA and Wilkinson, R.G. (2010). Animal Nutrition. Seventh Edition. Longman, New York.

Miah, M. Y., Rahman, M. S., Islam, M. K., \& Monir, M. M. (2004). Effects of saponin and L-carnitine on the performance and reproductive fitness of male broiler. Int J Poult Sci, 3, 530-533.

Nuriyasa, I. M., Puspani, E., \& Yupardhi, W. S. (2018). Performance and carcass of local rabbit (Lepus nigricollis) fed concentrate on different levels based on carrot leaf waste (Daucus carota L.). International journal of life sciences, 2(3), 13-19.

Nuriyasa, M. (2012). Respon Biologi Serta Pendugaan Kebutuhan Energi dan Protein Ternak Kelinci Kondisi Lingkungan berbeda Di Daerah Dataran Rendah Tropis. Disertasi. Program Pasca Sarjana. Universitas Udayana. Denpasar.

Oliveira, T. Í. S., Rosa, M. F., Cavalcante, F. L., Pereira, P. H. F., Moates, G. K., Wellner, N., ... \& Azeredo, H. M. (2016). Optimization of pectin extraction from banana peels with citric acid by using response surface methodology. Food Chemistry, 198, 113-118. https://doi.org/10.1016/j.foodchem.2015.08.080

Pereira, A., \& Maraschin, M. (2015). Banana (Musa spp) from peel to pulp: ethnopharmacology, source of bioactive compounds and its relevance for human health. Journal of ethnopharmacology, 160, 149-163. https://doi.org/10.1016/j.jep.2014.11.008

Prasad, R., Karim, S. A., \& Patnayak, B. C. (1996). Growth performance of broiler rabbits maintained on diets with varying levels of energy and protein. World Rabbit Science, 4(2), 75-78.

Prawitasari, R. H., Ismadi, V. D. Y. B., \& Estiningdriati, I. (2012). Kecernaan protein kasar dan serat kasar serta laju digesta pada ayam arab yang diberi ransum dengan berbagai level Azolla microphylla. Animal Agriculture Journal, 1(1), 471-483.

Sartika, T., \& Raharjo, Y. C. (1991). Pengaruh Berbagai Tingkat Serat Kasar Terhadap Penampilan, Persentase Karkas pada Kelinci Rex.(prosiding). In Seminar Nasional Usaha Peningkatan Peternakan dan Perikanan (Vol. 1).

Soeparno, E. (2005). Ilmu dan Teknologi Daging Cetakan keempat.

Swamy, G. J., \& Muthukumarappan, K. (2017). Optimization of continuous and intermittent microwave extraction of pectin from banana peels. Food Chemistry, 220, 108-114. https://doi.org/10.1016/j.foodchem.2016.09.197

Tillman, A. D., Hartadi, H., Reksohadiprodjo, S., Prawirokusumo, S., \& Lebdosoekojo, S. (1998). Ilmu makanan ternak dasar.

Tribudi, Y. A., Tohardi, A., \& Rohayeti, Y. (2020). Pemanfaatan Jeringau Merah (Acorus Sp) Sebagai Pengganti Antibiotika Terhadap Performa Ayam Broiler Yang Diinfeksi Salmonella typhimurium. Majalah Ilmiah Peternakan, 23(2), 51-55.

Rochi, R., Dewi, G., \& Nuriyasa, I. (2020). Using banana peels in pellet rations to improve performance of local male rabbits (Lepus nigricollis). International Journal of Life Sciences, 4(3), 59-71.

https://doi.org/10.29332/ijls.v4n3.550 
Ulfah, M., \& Natsir, M. H. (2018). Pemanfaatan Sambiloto, Andrographis Paniculata Nees, Sebagai Aditif Pakan Untuk Meningkatkan Performan Ayam Pedaging. Jurnal Ilmu-Ilmu Peternakan (Indonesian Journal of Animal Science), 18(1), 11-24.

Wardhana, R. P., Satrya, F. D., \& Dewanti, R. (2014). Pengaruh Penggunaan Klobot Jagung Segar Dalam Ransum Terhadap Kecernaan Bahan Kering Dan Bahan Organik Serta Produksi Karkas Kelinci Peranakan New Zealand White Jantan. Buletin Peternakan, 38(3), 150-156.

Wiryawan, K. G., Suharti, S., \& Bintang, M. (2005). Kajian antibakteri temulawak, jahe dan bawang putih terhadap Salmonella typhimurium serta pengaruh bawang putih terhadap performans dan respon imun ayam pedaging. Media Peternakan, 28(2).

Wuysang, S., Rahasia, C. A., Umboh, J. F., \& Tulung, Y. L. R. (2016). Pengaruh penggunaan molases sebagai sumber energi pakan penguat dalam ransum terhadap pertumbuhan ternak kelinci. ZOOTEC, 37(1), 149155.

Xue, B., Yan, T., Ferris, C. F., \& Mayne, C. S. (2011). Milk production and energy efficiency of Holstein and Jersey-Holstein crossbred dairy cows offered diets containing grass silage. Journal of dairy science, 94(3), 1455-1464. https://doi.org/10.3168/jds.2010-3663 


\section{Biography of Authors}

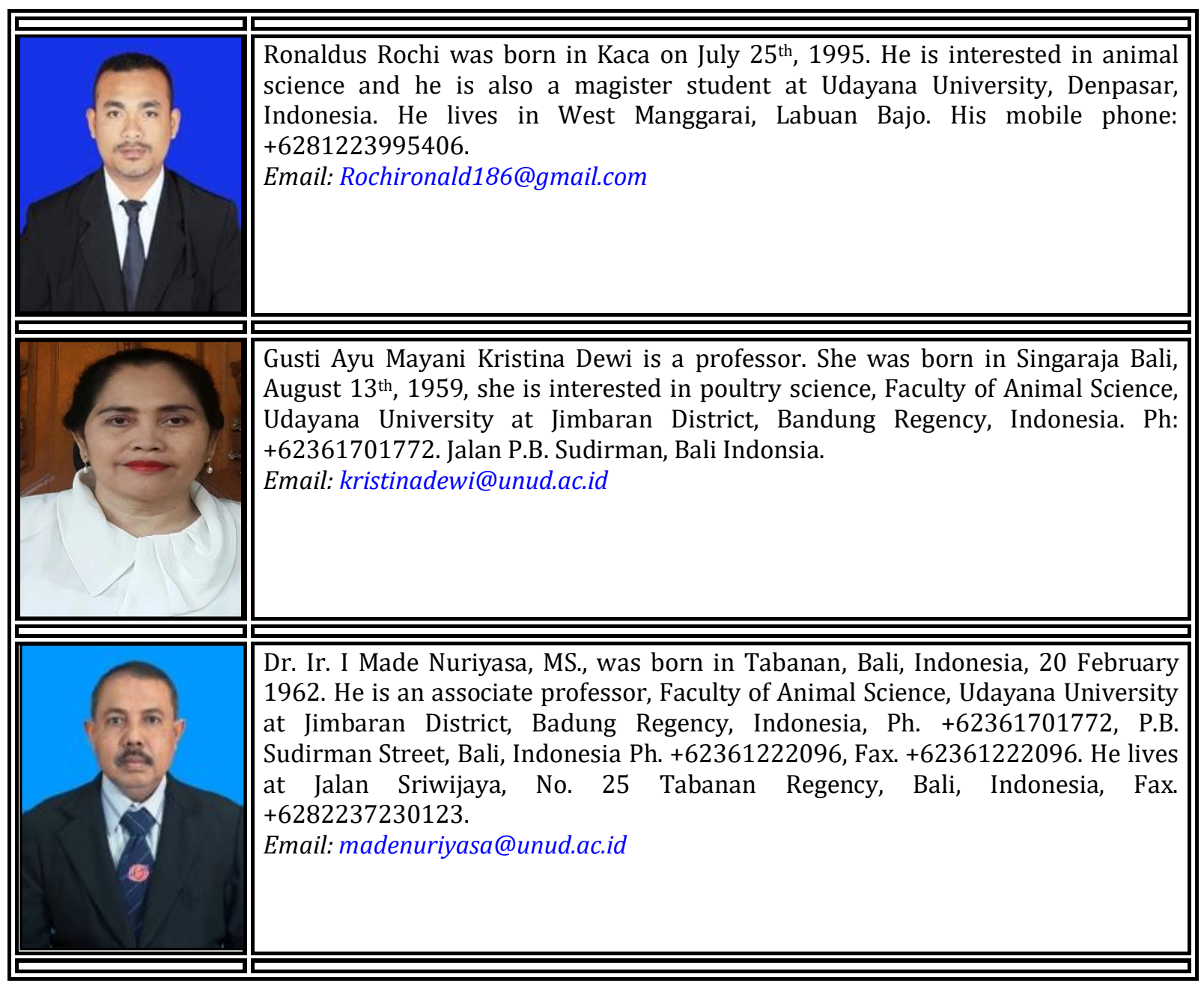

Rochi, R., Dewi, G., \& Nuriyasa, I. (2020). Using banana peels in pellet rations to improve performance of local male rabbits (Lepus nigricollis). International Journal of Life Sciences, 4(3), 59-71. https://doi.org/10.29332/ijls.v4n3.550 